\title{
PRODUCTION OPTIMIZATION AND CHARACTERIZATION OF BIOACTIVE COMPOUND AGAINST SALMONELLA FROM BACILLUS SUBTILIS KBB ISOLATED FROM NEPAL
}

\author{
Dwij Raj Bhatta* and B.P.Kapadnis** \\ *Central Department of Microbiology, Tribhuvan University, Kirtipur, Kathmandu, Nepal. \\ **Department of Microbiology, University of Pune, Pune, India.
}

\begin{abstract}
The present study aimed to isolate bioactive Bacillus spp. against multidrug resistant Salmonella and many other gram-negative bacterial pathogens. Altogether five bioactive Bacillus were isolated from soil samples of Nepal and identified as Bacillus licheniformis, Bacillus subtilis, Bacillus pumilus, Bacillus sp. and Bacillus cereus respectively by conventional techniques and DNA sequencing of the 16S rRNA gene. In all five isolates, the isolate Bacillus subtillis KBB was most potent antagonist of multidrug resistant Salmonella as tested by agar disc diffusion method. The bioactive compound production was optimized and product was purified by TLC, and bioactive molecule was characterized UV, IR NMR and GCMS and identified as peptide compound.
\end{abstract}

Key words: Bacillus; Bioactivity; Production optimization; Peptide compounds; One step solvent extraction; Antibacterial spectrum.

\section{INTRODUCTION}

Emergence of multidrug resistance among bacterial pathogens of hospital environment, domestic and industrial environment and in biofilms is reported globally. Hence, effective treatment systems using conventional antibiotics are failed. Since, the pace of new drug discovery is slower than the rate of emergence of resistance, consequently once easily treated infections are now becoming fatal and untreatable. (Maillard 2002; Stickler 2002; Gilbert and McBain 2003; Braoudaki and Hilton 2004). Therefore, screening of potent antibiotic producing microorganisms from the nature and development of novel, broad-spectrum antibiotics specifically targeting the individual bacterial virulence factors is required as for alternative strategies of antimicrobial therapy (Chopra et al. 2002). Bacillus subtilis is known to produce many antibiotics previously and is generally regarded as safe (GRAS) organisms (Zheng and Slavic 1999; Schallmey et al. 2004; Stein 2005). The antimicrobial compounds of Bacillus subtilis isolated by ammonium sulphate precipitation from culture broth showed antimicrobial activity against various foodborne pathogens such as Bacillus cereus, Listeria monocytogen and Salmonella Typhimurium. However, there are no specific reports available on the anti-Salmonella activities of Bacillus spp. (Bizani et al. 2005). Therefore, in present study, an attempt was made for isolation of novel Bacillus subtilis strain and also for production, extraction and characterization of partially purified anti-salmonella compound from the isolate.

\section{MATERIALS AND METHODS}

\section{Isolation and screening of bioactive Bacillus from soil samples}

Standard bacteriological media (Hi-media, Mumbai, India) and other chemicals of analytical grade were used in the present study. Bacillus spp. were isolated from 10 soil samples randomly collected in the sterile polypropylene bags from cultivated and barren lands in and around Kathmandu by spread plate technique (Collins and Lyne 1989; Priest and Grigoriva 1990). The antimicrobial activity of Bacillus isolate was checked by cross streaking technique. The overnight growth of each target culture viz; Salmonella Typhi, E. coli, Staphylococcus aureus was streaked across the growth of Bacillus isolates on NA plate and incubated for $24 \mathrm{~h}$ at $37^{\circ} \mathrm{C}$. Absence of growth adjacent to Bacillus growth indicated inhibition of target culture. The bioactivity of the Bacillus isolates was further tested by modified agar disc diffusion technique using Bacillus lawn Agar discs against target cultures viz; Salmonella Typhi, E. coli and Staphylococcus aureus. The Bacillus isolates that showed broad spectrum and bigger inhibition Zone (IZ) against representative target cultures of Salmonella were assumed to be promising bioactive Bacillus isolates. 
Identification of Bacillus isolates by conventional method and by 16S rRNA gene sequence analysis:

Promising Bacillus isolates were characterized using the tests prescribed in Bergey's Manual of Systematic Bacteriology (Berkley et al. 1984; Claus and Berkley 1986; and Collins and Lyne 1989). All Bacillus isolates were identified to species level by 16S rRNA gene sequence analysis using the taxonomy approach (Stackebrandt and Goebel, 1994).The nucleotide sequence analysis of the $16 \mathrm{~S}$ rDNA of the isolates was done at NCBI server using BLAST-n (www.ncbi.ncm.gov/blast) by aligning the partial sequences obtained with the primers mentioned above. Similarity search for the nucleotide sequence of $16 \mathrm{~S}$ rDNA of the test isolates done online at the www.ncbi.nlm.nih.gov using BLAST search programme with default parameter for the nucleotide database of Genbank, revealed the tentative identification of the isolates.

\section{Antibacterial spectrum of culture supernatant of promising bioactive Bacillus}

The primarily screened bioactive Bacillus subtilis KBB isolate was then inoculated into $100 \mathrm{ml} \mathrm{LB}$ broth and incubated for $24 \mathrm{~h}$ at $37^{\circ} \mathrm{C}$. After incubation, $50 \mathrm{ml}$ of culture broth was transferred to another $100 \mathrm{ml}$ of sterile LB broth in a $250 \mathrm{ml}$ conical flask, and incubated for $48 \mathrm{~h}$ at $37 \mathrm{U} \mathrm{C}$ in the incubator shaker $(150 \mathrm{rpm})$. An aliquot $(10 \mathrm{ml})$ of culture broth was withdrawn from flask after 36hrs and centrifuged at 10,000 rpm for $15 \mathrm{~min}$. The supernatant was filtered through 0.22 ìm Millipore membrane filter (Sartorius, Germany). An aliquot (5 $\mu \mathrm{l}$ ) of each culture supernatant was spotted onto MHA plate spread inoculated with overnight growth of target cultures. After incubation at $37^{\circ} \mathrm{C}$ for $18-24 \mathrm{~h}$, the plates were observed for inhibition of target cultures.

\section{Selection of medium of antimicrobial production}

The Bacillus subtilis KBB was inoculated into $500 \mathrm{ml} \mathrm{LB}$ broth (pH 7.0) in $1000 \mathrm{ml}$ flask and incubated for $24 \mathrm{~h}$ at $45^{\circ} \mathrm{C}$. After incubation, 50ml culture was inoculated to $250 \mathrm{ml}$ conical flasks each containing $100 \mathrm{ml}$ Nutrient broth, Mueller Hinton broth, LB broth, and LB broth supplemented with additional carbon source (1\% glucose, sucrose, and maltose) along with LB broth medium containing $1 \%$ maltose, $0.1 \% \mathrm{MnCl}_{2}$ and $0.1 \% \mathrm{KNO}_{3}(\mathrm{pH} 6.8)$. All flasks were incubated at $37^{\circ} \mathrm{C}$ in shaking condition (150 rpm) for $36 \mathrm{~h}$. After $36 \mathrm{~h}$ cell free supernatants were obtained from all flasks by centrifugation at $15000 \mathrm{rpm}$ for $15 \mathrm{~min}$. The antimicrobial activity of all cell free supernatants was determined against Salmonella Typhi W7 by spot on lawn method.

\section{The time course of antimicrobial compound production}

The time course of antimicrobial compound production by $B$. subtilis KBB was studied in LB broth with $1 \%$ Maltose, $0.1 \%$ $\mathrm{MnCl}_{2}$ and $1 \% \mathrm{KNO}_{3}$ (Bacillus broth) ( $\mathrm{pH}$ 6.8) for 5 days against target organism Salmonella Typhi.

Bacillus subtilis KBB (2 ml, $10^{6}$ cells $\left./ \mathrm{ml}\right)$ was inoculated into $200 \mathrm{ml}$ Bacillus broth (pH 6.8) and incubated in shaker incubator (150 rpm) for 5 days at $37^{\circ} \mathrm{C}$. At every $12 \mathrm{~h}$ interval, $10 \mathrm{ml}$ of culture was withdrawn from the flask. The growth was determined in terms of OD at $600 \mathrm{~nm}$. Part of the culture suspension was centrifuged (15000 rpm) and the supernatant was filtered through $0.22 \mu \mathrm{m}$ pore size membrane filter (Sartorius, Germany). The supernatant was assayed for protease activity as well as antimicrobial activity against Salmonella Typhi by spot on lawn method (Korenblum et al. 2005).

\section{Assay of antimicrobial activity in terms of Arbitrary units (AU)}

Antimicrobial activity was determined in terms of Arbitrary units (AU) which is defined as the reciprocal of the highest dilution of the supernatant that inhibited target organism $\mathrm{x}$ 1000 , divided by the volume of supernatant applied on the spot. Two-fold dilutions of the supernatant were made in sterile distilled water. $5 \mu \mathrm{l}$ of each dilution spotted on MHA plates (pH 7.2) seeded with Salmonella Typhi W7 (10 ${ }^{6}$ cells/ $\mathrm{ml}$ ). These plates were incubated at $37^{\circ} \mathrm{C}$ for $24 \mathrm{~h}$ (Korenblum et al. 2005). The increase in the antimicrobial activity was detected up to $3^{\text {rd }}$ day of fermentation (36 h) and slight decrease thereafter. It was thought that the host protease production might have resulted in the decrease of activity. Therefore, along with time course of production the protease activity was also assayed by Anson modified method (Anson 1939).

\section{Determination of temperature stability of culture supernatant bioactivity}

The effect of temperature, $\mathrm{pH}$, enzymes and solvents on the stability of bioactive compounds in culture supernatant (filter sterilized) of Bacillus KBB by the method of Korenblum et al. (2005). Each assay was performed three times in duplicate (Teo and Tan 2005).

\section{Extraction of bioactive principle from culture supernatant of Bacillus subtilis $K B B$}

In present study the antimicrobial compound was extracted by one step solvent extraction procedure by modification of Bligh and Dyer method 1959 (www.cyberlipid.org). The culture supernatant was mixed with equal volume of chloroform and agitated vigorously in a separating funnel. Absolute methanol (4 times the culture supernatant) was added slowly to it. The aggregate / precipitate observed at the interfacial region was collected in a petridish and evaporated. The residue was termed as crude antimicrobial compound (CAC). The residue ( $2 \mathrm{mg}$ ) was dissolved in $500 \mu \mathrm{l}$ of distilled water and its activity was checked by spot on lawn method against Salmonella Typhi .

\section{Partial purification of extracted antimicrobial substance}

From $100 \mathrm{ml}$ broth $200 \mathrm{mg}$ of CAC (dry residue) was obtained. This residue was distributed into 2 portions (100mg) in $500 \mu \mathrm{l}$ of absolute ethanol in sterile eppendorf tubes and incubated for $1 \mathrm{~h}$. Then the tubes were centrifuged and the ethanol layer was separated. The residue was kept in the incubator at $45^{\circ} \mathrm{C}$ to evaporate remaining ethanol. The residue from both the tubes was dissolved in $500 \mu$ l of sterile double distilled water, mixed togather, and extracted again with methanol chloroform method as described under 5.2.8 ii. The aggregate / precipitate from the interfacial region was collected in 
petridish and dried at $45^{\circ} \mathrm{C}$ in the incubator. The resulting residue $(100 \mathrm{mg}$ ) was distributed into small portions in sterile fresh set of eppendorf tubes. In both tubes $500 \mu \mathrm{l}$ of absolute ethanol was added and kept for $1 \mathrm{~h}$. Then the tubes were centrifuged and the residue from the tubes was dried at $45^{\circ} \mathrm{C}$. On re-dissolving the residue in $500 \mu \mathrm{l}$ of double distilled sterile water, a yellow coloured solution obtained to which $2 \mathrm{ml}$ of absolute methanol was added slowly. The aggregate / precipitate was observed and was kept in incubator at $45^{\circ} \mathrm{C}$ to evaporate methanol and water. The residue obtained was suspended in $500 \mu \mathrm{l}$ of absolute ethanol in eppendorf tube and ethanol was evaporated. The residue obtained was termed as partially purified antimicrobial compound. The partially purified antimicrobial compound was tested for purity by TLC using pre-coats (Polygram ${ }^{\circledR}$ Sil G/UV 254,Macherey-Nagel) and methanol: water: chloroform (10:20:5) as solvent system.

\section{Characterization of antimicrobial compound}

Biuret and Ninhydrin tests were performed to confirm protein nature of partially purified compound (Plummer 1997). Protein in the extract was estimated by Folin Lowery method using BSA as a standard (Plummer 1997).

Proteins were analysed in 14\% SDSPAGE by Laemmli method (1970). An aliquot (10 $\mu \mathrm{l})$ of partially purified antimicrobial compound (protein concentration $100 \mu \mathrm{g}$ per ml) was treated with an equal volume of SDS-PAGE sample buffer (125 mM Tris-HCl, pH 6.8, 4\% SDS, 20\% glycerol, 2\% bromophenol blue) and electrophoresed at $100 \mathrm{~V}$ at $28^{\circ} \mathrm{C}$ for $90 \mathrm{~min}$. The gel was stained with $0.25 \%$ coomassie brilliant blue in methanolacetic acid-water (40: 10: 50), and destained in the same solvent to observe the protein bands. A comparison was made with mobility of SDSPAGE standards (Sigma) (Korenblum et al. 2005; Bizani et al. 2005).

Determination of purity and activity of antimicrobial compound by TLC and bioautography

An aliquot $(5 \mu \mathrm{l})$ of partially purified antimicrobial compound (water solution) was spotted on 2 TLC precoats (Polygram ${ }^{\circledR}$ Sil G/UV 254,Macherey-Nagel) and separated with methanol: water: chloroform $(10: 20: 5)$ solvent system. The original concentration of each extract in this experiment was $100 \mathrm{mg} /$ $\mathrm{ml}$. One of the dried plates was kept on petriplate and overlaid with MHA seeded with Salmonella Typhi W7 and incubated at $37^{\circ} \mathrm{C}$ for $18 \mathrm{~h}$ and observed for inhibition. Second plate was developed with Ninhydrin. The distance moved by active compound and solvent was recorded and the Rf value of active compound determined (Plummer 1997). In this experiment the position of active compound (as indicated by inhibition Zone) on overlaid TLC plate was located and compared with that detected by Ninhydrin.

\section{Determination of antimicrobial Spectrum of partially purified compound}

The partially purified antimicrobial compound was dissolved in double distilled water $(100 \mathrm{mg} / \mathrm{ml})$ and $5 \mu \mathrm{l}$ of it was spotted on the lawn of target cultures (multi drug resistant Salmonella isolates). The plates were incubated for 24 h at 37ÚC. After incubation inhibition zones were recorded (Korenblum et al. 2005).

\section{Determination of minimum inhibitory concentration (MIC) of partially purified compound}

MIC of partially purified antimicrobial compound against $S$. Typhi and Staphylococcus aureus was determined by broth dilution technique. Briefly, the partially purified antimicrobial compound was dissolved in double distilled water (100mg/ $\mathrm{ml})$ and double dilution of the compound was made in nutrient broth. Then, $1 \mathrm{ml}$ inoculum $\left(10^{6} \mathrm{cfu} \mathrm{ml}^{-1}\right)$ of Salmonella Typhi and Staphylococcus aureus was added separately to an equal volume of two-fold dilutions of respective antibicrobial solution. For positive control, $1 \mathrm{ml}$ inoculum $\left(10^{6} \mathrm{cfu} \mathrm{ml}^{-1}\right)$ of target organisms was added to $1 \mathrm{ml}$ growth medium without antimicrobial. All the tubes were incubated for $24 \mathrm{~h}$ at $37^{\circ} \mathrm{C}$. The MIC was reported as the lowest concentration of antimicrobial substance that prevented visible growth (Cheesbrough 1993; Andrews 2001).

\section{UV, IR, GCMS and NMR analysis of bioactive molecule}

The UV absorption spectrum analysis was done using double beam UV spectrophotometer (UV 1601, Shimadzu Japan). The FTIR (Fourier Transform Infrared) spectrum was conducted using FTIR 8400 (Shimadzu, Japan). GC-Mass spectroscopy was conducted (GCMS QP5050, Shimadzu, Japan) to characterize bioactive compound. In present study ${ }^{1} \mathrm{H}$ (proton, i.e., PNMR) and ${ }^{13} \mathrm{C}$ (carbon- 13, i.e., CNMR) NMR spectroscopy (Varion mercury YH 300) was done to analyse the spectral data. Above-mentioned analysis was conducted at Garware Centre, Department of Chemistry, University of Pune, India, according to standard protocol.

\section{RESULTS}

\section{Antimicrobial spectrum Bioactive Bacillus isolates and their identification}

Altogether five bioactive Bacillus isolates viz; KBR, KBB, KBY, KBC and KBA, showed activity against E. coli, S. Typhi and Staphylococcus aureus in primary screening by crossstreaking method. Their bioactivity was subsequently confirmed by agar disc diffusion method. In all five bioactive isolates isolate $\mathrm{KBB}$ was found to be more potent antagonist of multidrug resistant Salmonella as tested by agar disc diffusion method (Plate 1).

It was identified as Bacillus spp. on the basis of morphological and biochemical characteristics by conventional techniques (Berkley et al. 1984; Claus and Berkeley 1986 (Plate 2).

The partial sequence of the $16 \mathrm{~S}$ rRNA gene of the strain KBB was also obtained with different primers which showed closest homology with some known sequences of Bacillus sp. in Gene bank after first five blast hits (On NCBI BLAST). Therefore, the strain was tentatively identified as Bacillus subtillis and the partial sequence was submitted to NCBI gene bank with accession number EF42850 (Fig 1). 
Plate 1: Bioactivity of Bacillus subtilis KBB against Salmonella Typhi W7
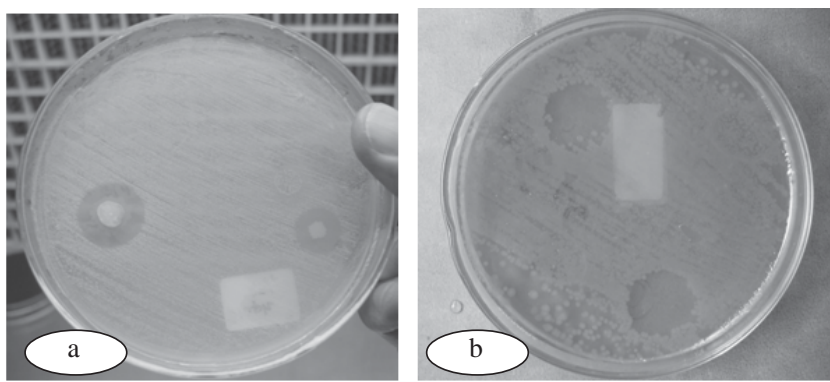

a. Agar disc method, b. Spot on lawn method

Plate 2: Photomicrograph of Bacillus subtilis KBB

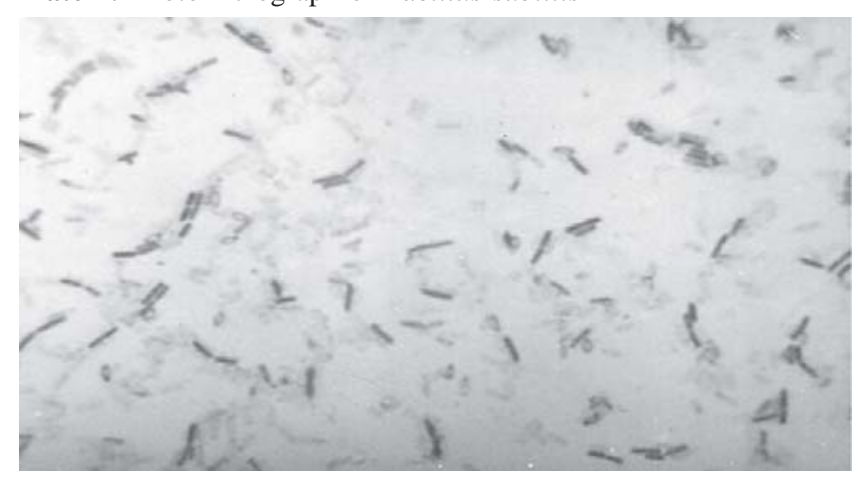

Strain KBB

Primer used for sequencing 343R

Homology with Bacillus subtilis $\mathbf{9 8 \%}$

Sequence is submitted to Gene bank with accession numberEF428450

TCAGTGTGGCGATCACCCTCTCAGGTCGGCTACGCATCGTTGCCTTGGTGAGCCGTTACTC ACCAACTAGCTAATGCGCCGCGGGTCCATCTGTAAGTGGTAGCCGAAGCCACCTTTTATG TTTGAACCATGCGGTTCAAACAACCATCOGGTATTAGOCOOGGTTTCOOGCCACTTATCOCAGT CTTACAGGCAGGTTACCCACGTGTTACTCACCCGTCCGCCGCTAACATCAGGGA GCAAGCTCCCATCTGTCCGCTCGACTTGCATGTATTAGGCACGCCGCCAGCGTTCGTCCT GAGCCATGATCAAACTCTGGAGCTGCT

\section{First five hits}

gi|29164925|gb|AY219900.1| Bacillus subtilis 16S ribosomal RNA g 565 2e-158 gi|93210287|gb|DQ462193.1| Bacillus subtilis strain MP-3 16S ... 559 1e-156 gi|71493066|gb|DQ122328.1| Bacillus sp. iCTE54 16S ribosomal ... $\underline{559}$ 1e-156 gi|71493065|gb|DQ122327.1| Bacillus sp. iCTE51 16S ribosomal ... $\underline{559}$ 1e-156 gil71493064|gb|DQ122326.1 Bacillus sp. iCTE50 16S ribosomal ... $\underline{559}$ 1e-156

\section{Strain KBB}

Primer used for sequencing 530F

Homology with Bacillus subtilis 99\%

CGATGTCGGATATTGGGCGTAAGGGCTCGCAGGCGGTTTCTTAAGTCTGATGTGAAAGCCC CCGGCTCAACCGGGGAGGGTCATTGGAAACTGGGGAACTTGAGTGCAGAAGAGGA GAGTGGAATTCCACGTGTAGCGGTGAAATGCGTAGAGATGTGGAGGAACACC AGTCGCGAAGGCGACTCTCTGGTCTGTAACTGACGCTGAGGAGCGAAAGCGT GGGGAGCGAACAGGATTAGATACCCTGGTAGTCCACGCCGTAAACGATGAGTGCTAAG TGTTAGGGGGTTTCOGCOOCTTAGIGCTGCAGCTAACGCATTAAGCACTOOGCCTGGGGAGTAC GGTCGCAAGACTGAAACTCAAAGGAATTGACGGGGGCCCGCACAAGCGGTGGAGCATGT
GGTTTAATTCGAAGCAACGCGAAGAACCT

gi|59859126|gb|AY913755.1| Bacillus subtilis strain CICC10078... $825 \quad 0.0$

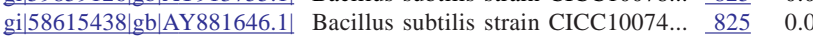

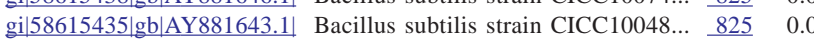
gi|58615428|gb|AY881636.1| Bacillus subtilis strain CICC10026... $\quad 825 \quad 0.0$

\section{Strain KBB}

Primer used for sequencing 704F

Homology with Bacillus subtillis 100\%

CCGTGGCGAGGCGACTCTCTGGTCTGTAACTGACGCTGAGGAGCGAAAGCGTGGGGAGC GAACAGGATTAGATACOCTGGTAGTOCAOGCOGTAAAOGATGAGTGCTAAGIGTTAGGGGGTTTCOGC

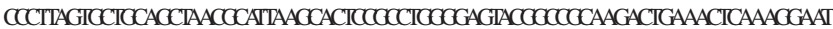
TGACGGGGGOCOGCACAAGOGGTGGAGCATGTGGTTTAATTCGAAGCAACGOGAAGAACCTTA OCAGGTCTTGACATCCICTGACAATCCTAGAGATAGGAOGTCOOCTTCGGGGGCAGAGTGACA GGTGGTGCATGGTTGTCGTCAGCTCGTGTCGTGAGATGTTGGGTTAAGTCCCGCAACG AGCGCAACCCTTGATCTTAGTTGCCAGCATTCAGTTGGGCACTCTAAGGTGAC TGCCGGTGACAAACCGGAGGAAGGTGGGGATGACGTCAAATCATCATGCCCCT TATGACCTGGGCTACACACGTGCTACAATGG

\section{First five hits}

gi|48596227|gb|AY590138.1| Bacillus sp. SXQ-2004 16S ribosomal R $1019 \quad 0.0$ gi|47118164|gb|AY601724.1| Bacillus sp. AMX-4 16S ribosomal RNA $\underline{\underline{1011}} 0.0$ gi|47118163|gb|AY601723.1| Bacillus sp. WL-3 16S ribosomal RNA g $\underline{1011} \quad 0.0$ gi|47118162|gb|AY601722.1| Bacillus subtilis isolate WL-7 16S... 10110.0 gi|93211252|gb|DQ474759.1| Bacillus subtilis strain E9 16S ri... $1011 \quad 0.0$

Figure 1: 16S rRNA gene sequencing of bioactive Bacillus subtillis KBB.

\section{Time course of antimicrobial activity from Bacillus subtilis KBB}

Bigger Zone of inhibition of Salmonella Typhi was observed by the cell free culture supernatant of $B$. subtilis grown in LB broth supplemented with $1 \%$ maltose, $0.1 \% \mathrm{MnCl}_{2}$ and $0.1 \%$ $\mathrm{KNO}_{3}$ (pH 6. 8) then by the culture supernatant of Nutrient broth, Mueller Hinton broth, LB broth, LB broth supplemented with carbon source ( $1 \%$ glucose, sucrose, and maltose). This medium was designated as Bacillus broth, which enhanced the production of anti-Salmonella compounds. Time course of antimicrobial compound production by $B$. subtilis KBB in Bacillus broth was monitored over a period of 5 days. Maximum activity was observed on the $3^{\text {rd }}$ day. The rate of antimicrobial compound production correlated with growth rate of Bacillus subtilis KBB and was highest (1600 AU/ml) in the late log phase. During the course of antimicrobial compound production, initial $\mathrm{pH}$ of the fermentation broth on first day was neutral and was raised to 7.5 after $12 \mathrm{~h}$ and 8.2 after $24 \mathrm{~h}$ and it remained constant $24 \mathrm{~h}$ onwards. During the course of antimicrobial compound production the protease activity was negligible $(0.27 \mathrm{unit} / \mathrm{ml})$ and remained same upto $96 \mathrm{~h}$. It was same even when there was maximum production of antibiotics at $36 \mathrm{~h}$. It indicates that the organism did not produce significant amount of protease and therefore, no possibility of loss of activity.

Table 1: Time course of antmicrobial activity of Culture Supernatant of Bacillus subtilis KBB

\begin{tabular}{|c|c|c|c|c|c|}
\hline Incubation (h) & Growth (OD $\mathbf{~ 6 0 0 0}$ ) & Activity (AU/ml) & Zone of inhibition $^{+}$(mm) & pH of CS & Protease (Units/ml) \\
\hline 0 & 0.223 & 0 & NZ & 6.8 & \\
\hline 12 & 1.113 & 200 & 5 & 7.5 & ND \\
\hline 24 & 1.773 & 400 & 15 & 8.2 & 0.27 \\
\hline 36 & 1.995 & 1600 & 16 & 8.2 & ND \\
\hline 48 & 1.888 & 1600 & 18 & 8.2 & 0.27 \\
\hline 72 & 1.231 & 800 & 15 & 8.2 & 0.27 \\
\hline 96 & 0.914 & 400 & 12 & & 0.23 \\
\hline
\end{tabular}

${ }^{+}$Against S.TyphiW7 


\section{Stability of antimicrobial compound at different} temperatures

When the antimicrobial activity of the stored culture supernatant (stored for one month at $-20^{\circ} \mathrm{C}, 4^{\circ} \mathrm{C}$, and at $28^{\circ} \mathrm{C}$ ) was determined against Salmonella Typhi, the activity was similar to that of control (before storage). It was concluded that the antimicrobial compound did not lose any activity even after one month storage in refrigerator and at $28^{\circ} \mathrm{C}$, which indicates that the compound do not undergo any kind of degradation during storage at varied temperature.

Effect of temperature, pH, enzymes, and solvents on bioactivity of culture supernatant of Bacillus subtilis KBB

The antibacterial activity was not affected until $90^{\circ} \mathrm{C}$ and then decreased slightly thereafter and lost completely after autoclaving. These results indicated that the antimicrobial compound seems to be highly thermostable upto $90^{\circ} \mathrm{C}$.

The initial $\mathrm{pH}$ of the culture supernatant was 8.2 and was adjusted to 2.5, 3.8, 4.2,5.2,5.8,6.8 with citrate phosphate buffer and raised to $\mathrm{pH} 9.8,10.2$ by carbonate-bicarbonate buffer. Antimicrobial activity was observed within wide $\mathrm{pH}$ range. However, the activity was affected at extreme $\mathrm{pH}$.

The culture supernatant of the $B$. subtilis KBB was treated with enzymes as described in methodology. After the enzyme treatment the supernatant was tested for antimicrobial activity. The inhibition zone diameter produced by supernatant treated with proteinase $\mathrm{K}$, pronase and $\propto$ chymotrypsin, was smaller than that of untreated sample. It indicates that the antimicrobial compound is partially susceptible to proteinase $\mathrm{K}$, pronase and $\propto$ chymotrypsin and insensitive to pepsin. There is no loss of antimicrobial activity observed with ethyl alcohol, methanol, acetone, and Chloroform.

\section{Solvent extraction of antimicrobial compound}

In the present study, $100 \mathrm{mg}$ of dry residue was obtained from $100 \mathrm{ml}(1 \mathrm{~g} / \mathrm{l})$ of cell free supernatant and termed as crude antimicrobial compound (CAC). The CAC was completely soluble in distilled water, giving yellow coloured solution. The $\mathrm{pH}$ of the solution was acidic ( $\mathrm{pH} 3.5)$. Subsequently, $2 \mathrm{mg}$ of CAC residue was dissolved separately in $500 \mu \mathrm{l}$ of distilled water, and it was highly bioactive active against Salmonella Typhi. The residue was insoluble in acetone, chloroform, ethanol and methanol. In acetone in a Petridis the residue formed sticky and hard structure like calcification. In chloroform also it was completely insoluble. However, it was soluble in 25\% methanol and ethanol.

The partial purification of the compound by successive solvent washing resulted in $50 \mathrm{mg}$ of dry residue from $100 \mathrm{ml}$ of culture supernatant. Finally obtained residue was termed as partially purified antimicrobial compound. The partially purified residue was also soluble in water but not in acetone, chloroform, and absolute methanol and ethanol. The aqueous solution was highly acidic in nature in water solution, and yellow coloured with characteristic smell. The solution was distributed in eppendorf tubes in small quantity. Some were kept at $28^{\circ} \mathrm{C}$ and few were kept at $5^{\circ} \mathrm{C}$ and tested for stability. The compound was found bioactive even after one-year storage at $28^{\circ} \mathrm{C}$. The partially purified antimicrobial compound was tested for purity by thin layer chromatography (Polygram ${ }^{\circledR}$ Sil G/UV 254,Macherey-Nagel) and only one spot observed with Rf value 0.5 confirmed the purity of the compound.

Table 2: Antimicrobial spectrum of partially purified compound from Bacillus subtilis KBB

\begin{tabular}{|c|c|c|c|}
\hline \multicolumn{2}{|c|}{ TARGET CULTURES } & $\begin{array}{c}\text { Zone of inhibition with } \\
\text { anticrobial compound }\end{array}$ \\
\hline Isolate & Organism & Antibiotic resistance* & ++ \\
\hline W1 & S. Typhi phage type UVS1 & AR & ++ \\
\hline W7 & S. Typhi phage type A & AR & + \\
\hline N3 & S. Typhi phage type E1 & MDR & ++ \\
\hline N5 & S. Typhi phage type UVS4 & MDR & + \\
\hline B1 & S. Typhi phage type E1 & MDR & ++ \\
\hline B4 & S. Typhimurium, & MDR & + \\
\hline B6 & S. Typhimurium, & MDR & + \\
\hline W2 & S. Typhimurium & MDR & + \\
\hline W1 & S. Paratyphi A & AR & + \\
\hline N13 & S. Paratyphi A & MDR & + \\
\hline D13 & S. Enteritidis & MDR & ++ \\
\hline E13 & Citro. Fruendii & ND & ++ \\
\hline D24 & Ent. Agglomerans & ND & + \\
\hline D28 & E. coli & MDR & ++ \\
\hline St2 & M. morganii & ND & + \\
\hline- & P. mirabilis & ND & ++ \\
\hline
\end{tabular}

** Suceptibility of target cultures to partially purified compound by spot on lawn method (Inhibition zone produced by partially purified compound $100 \mathrm{mg} / \mathrm{ml}$ solution and $5 \mu \mathrm{l} \mathrm{spot}$ )

+++ inhibition Zone $25 \mathrm{~mm}$; ++ inhibition Zone $\geq 15 \mathrm{~mm}$; + inhibition Zone $\leq 15 \mathrm{~mm}$

* Refer chapter 3 Table 3. 3; and chapter 2 Table 2. 8.

$\mathrm{AR}=$ ampicillin resistant; $\mathrm{MDR}=$ multidrug resistant; ND antibiotic sensitivity not determined. 


\section{Proteinaceous nature of antimicrobial compound}

The property of partially purified compound as studied by Biuret test, and Ninhydrin test confirmed its proteinaceous nature. In TLC plate the compound was detected with Ninhydrin reagent after heating the plates at $100^{\circ} \mathrm{C}$ for $5 \mathrm{~min}$. Only one spot was observed with $0.5 \mathrm{Rf}$ value confirmed purity and protein nature of extracted antimicrobial compound. The protein concentration in the $100 \mathrm{mg} / \mathrm{ml}$ of partially purified compound was $0.87 \mathrm{mg} / \mathrm{ml}$ as determined by Folin Lowery method (Plummer, 1997). The compound was resolved in 14 \% gel. A single band in SDS PAGE approx. 14 KD confirmed the proteinaceous nature and low molecular weight of the antimicrobial compound.

\section{TLC bioautography}

Two thin layer chromatography plates (Polygram ${ }^{\circledR}$ Sil G/UV 254,Macherey-Nagel) of similar size were spotted with solution of partially purified antimicrobial compound at similar distance and fractionated with methanol: water: chloroform (10:20:5) solvent system. The original concentration of each extract in this experiment was $100 \mathrm{mg} / \mathrm{ml}$. A single spot of the compound with Rf value 0.47 observed on TLC plate developed with Ninhydrin confirmed, the presence of single compound in cell free supernatant. The Rf value 0.5 of bioactive spot observed on second TLC plate seeded with target culture was similar to that detected in first plate confirmed the compound was bioactive (Plate 2).

Plate 2: TLC bioautography of antimicrobial compound of Bacillus subtilis KBB

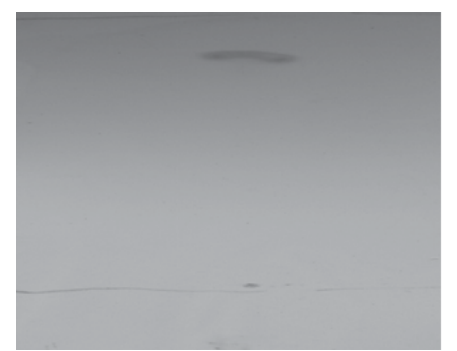

(a)

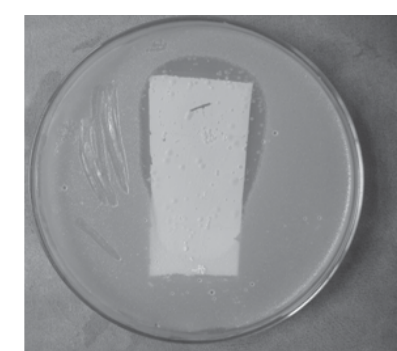

(b) (a) Single spot in TLC visualized with Ninhydrin (b)TLC bioauto graphy

\section{Antimicrobial spectrum of partially purified antimicrobial compound}

The spot on lawn method indicated that the partially purified compound was active against many gram negative pathogens viz; MDR Salmonella, E. coli etc. and Staphylococcus aureus.
Minimum inhibitory concentration of partially purified antimicrobial compound against Salmonella Typhi and $S$. aureus

The minimum inhibitory concentration of partially purified antimicrobial compound was found to be $125 \mathrm{ìg} / \mathrm{ml}$ for Staph. aureus and $250 \mathrm{ig} / \mathrm{ml}$ for Salmonella Typhi .

\section{Characterization of antimicrobial compound by UV, IR, GCMS, NMR spectrum analysis}

The low molecular weight of the antimicrobial compound with a single band with SDS PAGE and single spot developed with Ninhydrin on TLC plate indicated the purity of the compound. The HPLC peak analysis, UV Spectrum, IR Spectrum, GCMS Spectrum and NMR Spectrum supported the peptide nature of the compound. The UV absorption spectrum (UV 1601, Shimadzu Japan) of the antimicrobial compound was examined between 190 and $600 \mathrm{~nm}$. The compound showed absorption maxima at $205 \mathrm{~nm}$ was corresponding to characteristic absorption of peptide bonds. A shoulder at $268 \mathrm{~nm}$ indicated the protein nature of the compound. The FTIR (Fourier Transform Infrared) spectrum (FTIR 8400,Simadzu, Japan) exhibited characteristic absorption valley at $1765 \mathrm{Cm}^{-1}$ (carboxyl group), valley at 1664.5 $\mathrm{Cm}^{-1}$ (Gausian amide bonds) and valley at $3138 \mathrm{Cm}^{-1}$ (hydrogen bonded $\mathrm{OH}$ groups). All indicated that substance contains peptide bonds. C- $\mathrm{NH}_{2}$ stretching was indicated by valley at $979 \mathrm{~cm}^{-1}$ and carbon - carbon stretching was indicted by valley at $1652 \mathrm{~cm}^{-1}$. The valley at $2665 \mathrm{~cm}^{-1}$ shows C-H stretching, valley at 619 shows 4-Amino quinaldine or $\mathrm{Na}$ acetate or C-C inplane bending, and valley at $14004.1 \mathrm{~cm}^{-1}$ shows symmetric $\mathrm{COO}^{-}$stretching. The $\mathrm{O}-\mathrm{H}$ stretching was indicted by valley at 3138 . All above characteristics valleys indicated peptide-based structure of the compound. The GCMass spectrum data was analysed (GCMS QP5050, Shimadzu, Japan). The analysis of all major peaks (molecular mass 207) indicated that compound closely resemble to peptide type antibiotics in the antibiotic library. But it also resembled to many antibiotics and mainly to silicon ( $\mathrm{Si}$ ) containing compounds in the library but not exactly. Therefore, the compound must be a new molecule. The ${ }^{1} \mathrm{H}$ NMR (Nuclear magnetic resonance, $500 \mathrm{MHz}){ }^{13} \mathrm{CNMR}$ spectra of the antimicrobial compound in $\mathrm{D}_{2} \mathrm{O}$ indicated presence of $13 \mathrm{H}$ and $19 \mathrm{C}$ in the sample. However, the complete structure elucidation of the compound and molecular formula could not be established in this study and further study is recommended (fig 2.,fig3,fig4.,fig.5)

Table 3: Physico-chemical properties of the antimicrobial compound from Bacillus subtilis KBB.

\begin{tabular}{|l|l|}
\hline \multicolumn{1}{|c|}{ Properties } & \multicolumn{1}{c|}{ Results } \\
\hline Colour & Dark brown when extracted and light yellow after purification \\
\hline Nature & Amorphous \\
\hline Yield (mg/lit) & 500 \\
\hline Solubility & $\begin{array}{l}\text { Water soluble and soluble in 25\% methanol, ethanol but insoluble in Absolute methanol and Ethanol and } \\
\text { acetone, chloroform }\end{array}$ \\
\hline UV $\lambda \max (\mathrm{nm})$ & 205 \\
\hline $\mathrm{IR}(\mathrm{KBr}) \mathrm{cm}-1$ & $\begin{array}{l}\text { Major valleys 1765 Cm-1 (carboxyl group), valley at 1664.5 Cm-1 (Gausian amide bonds) and valley at 3138 } \\
\mathrm{Cm}-1 \text { (hydrogen bonded OH groups), indicates peptide nature }\end{array}$ \\
\hline GC-MS $(\mathrm{m} / \mathrm{z})$ & Probable compound, Peptide \\
\hline
\end{tabular}




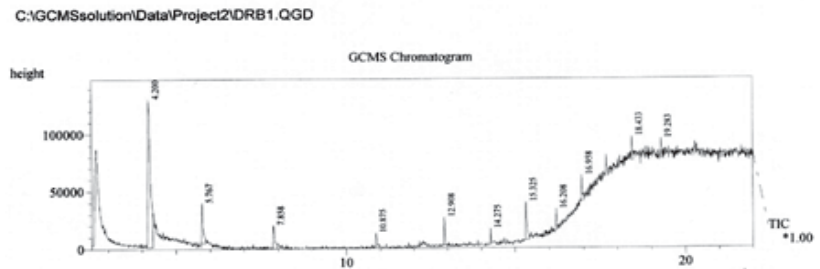

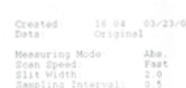

Fig 2: UV Spectra of antimicrobial compound of Bacillus subtilis KBB

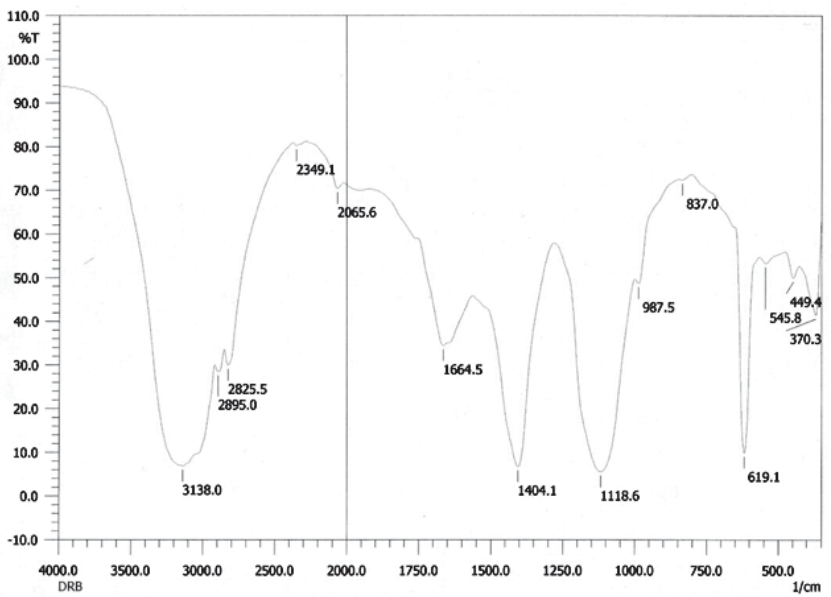

Fig 3: FTIR Spectra of antimicrobial compound from Bacillus subtilis KBB
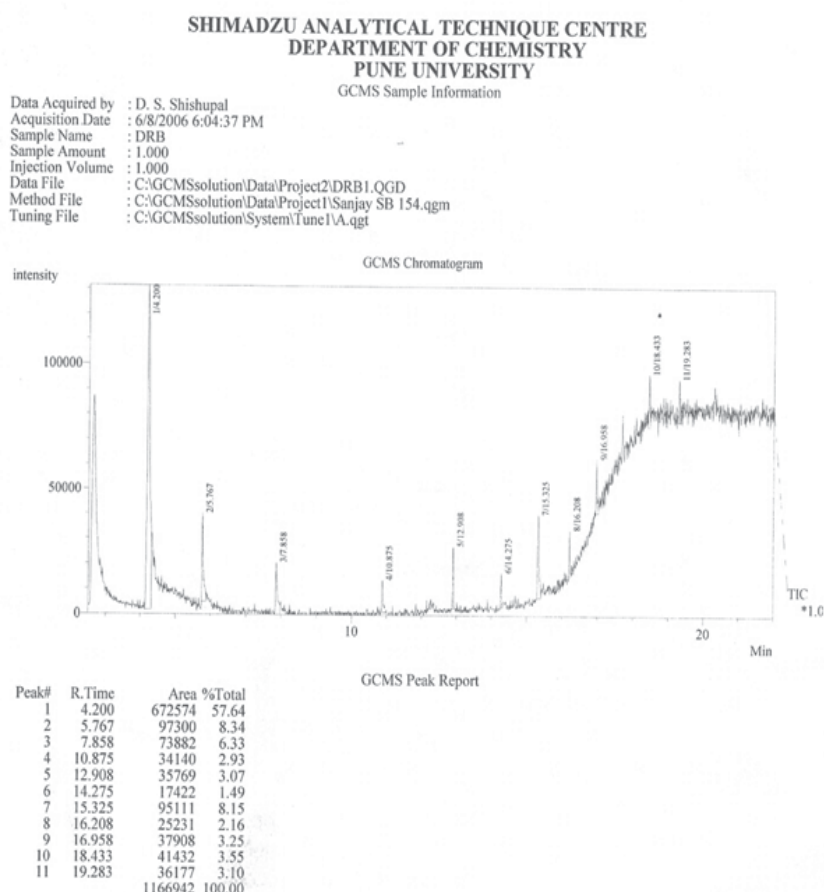

Fig. 4: GCMS spctra of antimicrobial compound of Bacillus subtilis KBB
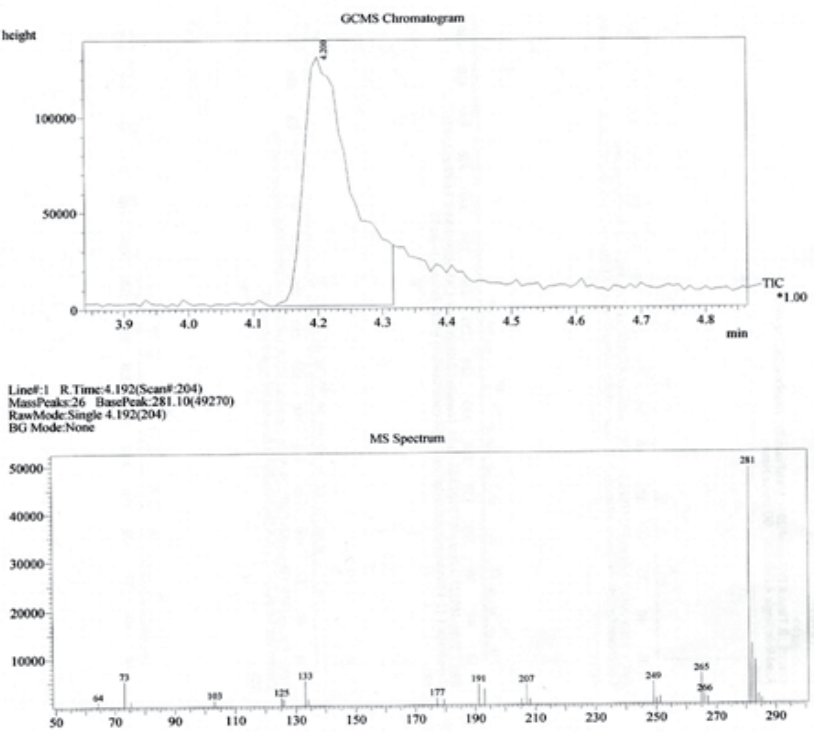

Fig 4: GCMS Spectra of antimicrobial compound of Bacillus subtilis KBB
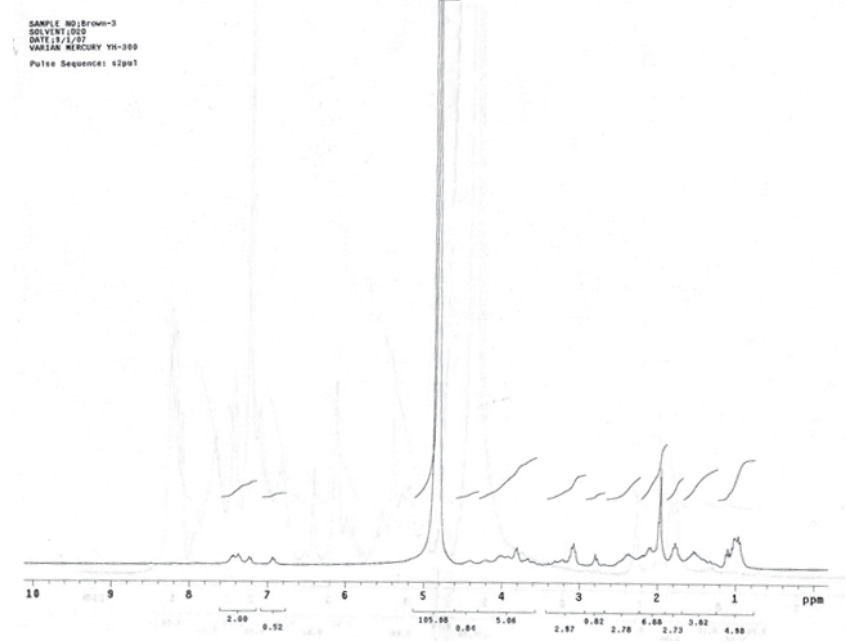

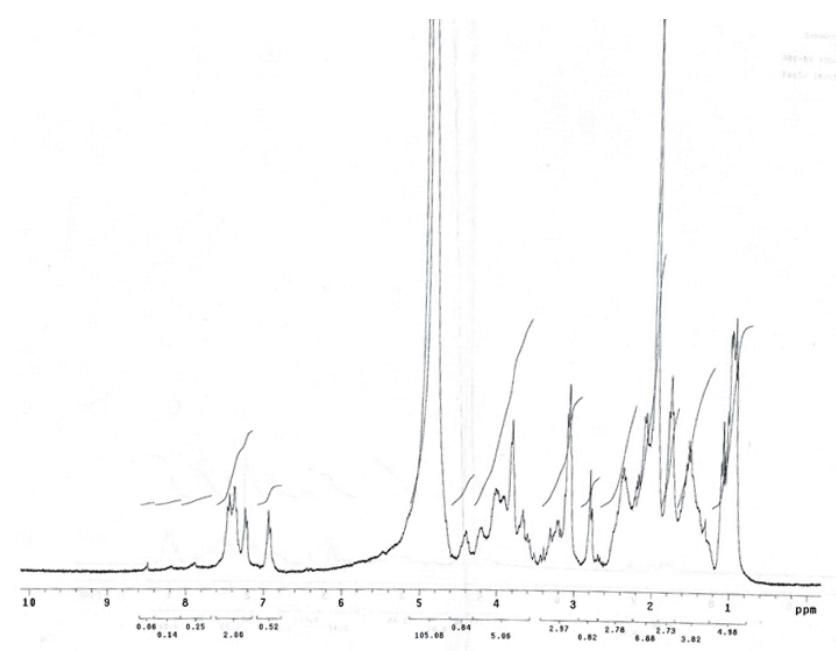




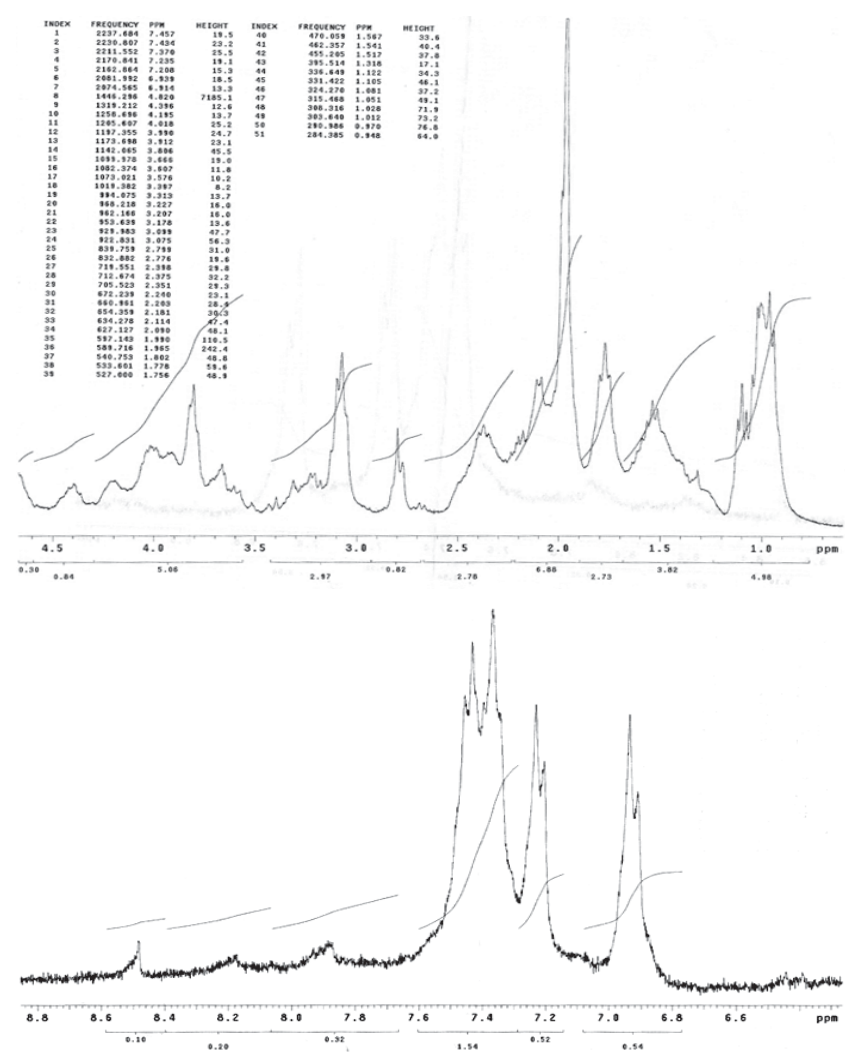

Fig 5: ${ }^{1} \mathrm{H}$ NMR spectra of antimicrobial compound of Bacillus subtilis KBB
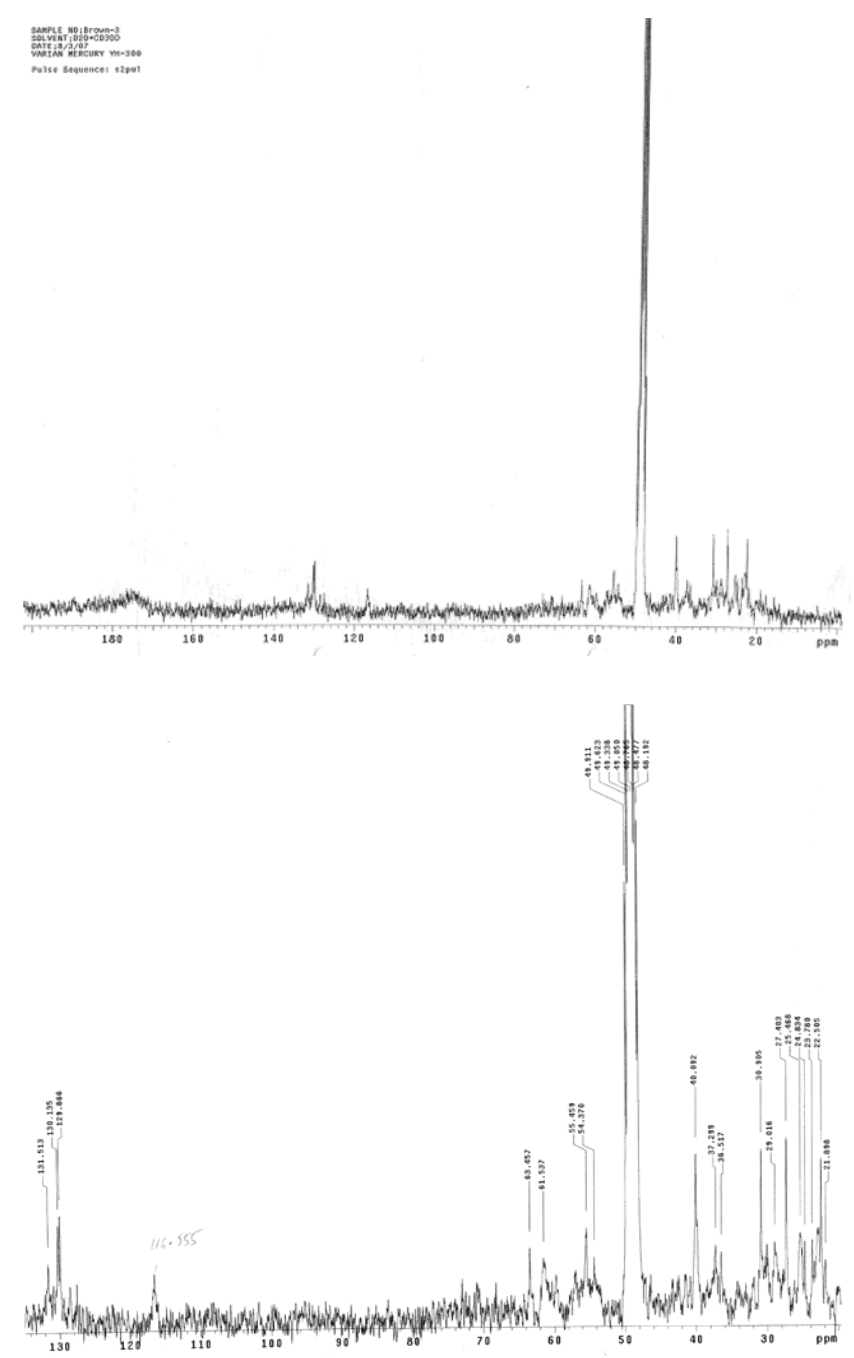

13C OBSERVE

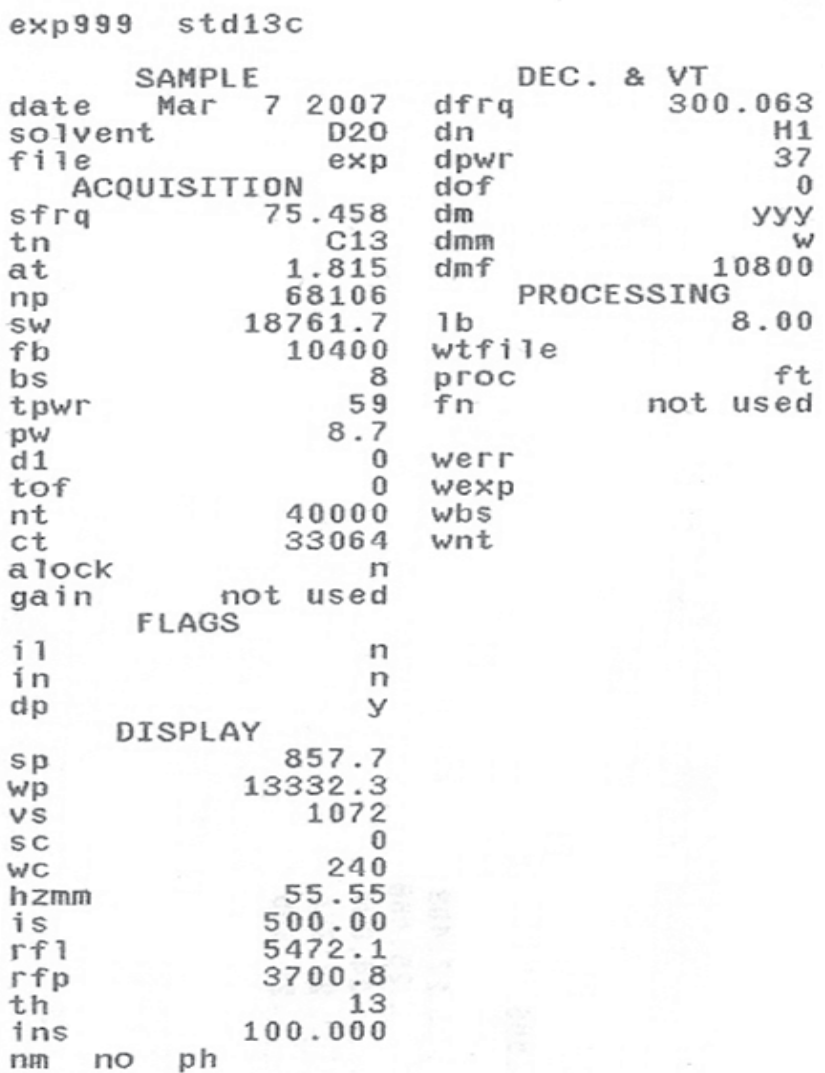

Fig 6: ${ }^{13} \mathrm{C}$ NMR spectra of the antimicrobial compound of Bacillus subtillis $\mathrm{KBB}$

\section{DISCUSSION}

The present study was based on previous studies, which have shown that the Bacillus subtilis produces thermo-stable proteinaceous antimicrobial factor, which remains stable in the presence of bile salt and solvents and can be used against animal and human pathogens (Seah et al. 2002).

In present study, one of the strain Bacillus subtilis KBB was found superior antagonist of many gram negative waterborne pathogens and inhibited the growth of MDR Salmonella serovars such as $S$. Typhi, $S$. Typhimurium, $S$. Enteritidis and $S$. Paratyphi A. There are various reports available on production of anti bacterial compound from Bacillus viz; lichenin by $B$. licheniformis, bacteriocins called cerein by Bacillus cereus, and pumilin production from Bacillus pumilus (Katz and Demain 1977; Pattnaik et al. 2001; Paik et al. 2000). Bacteriocin production by B. subtilis has been reported previously, and the best-characterized bacteriocins are subtilin, but reports on anti microbial activity against gram-negative enteric pathogens are scanty and very few reports are available on the broad-spectrum antimicrobial production (Jansen and Hirschmann. 1944; Stein 2005). However, therehave been no reports on anti-microbial activity of $B$. subtilis against multidrug resistant serovars of Salmonella.

Present study revealed production of low $\mathrm{pH}$ anti Salmonella compound by B. subtilis KBB, which also inhibits Proteus 
mirabilis, E. coli, Enterobacter agglomerans, Citrobacter frundii and Morganella morganii. Therefore, findings have established this strain as the potential broad-spectrum antagonists of waterborne pathogens.

In present study, the antimicrobial compound production from B. subtilis KBB was optimized using different liquid media, such as nutrient broth, Mueller Hinton broth, LB broth, and LB broth with additional carbon source (1\% glucose, sucrose, and maltose) along with source of manganese. LB broth medium containing $1 \%$ maltose and $0.1 \% \mathrm{MnCl}_{2}$ and $0.1 \%$ $\mathrm{KNO}_{3}$ was found most suitable for the production of antisalmonella compound. Manganese has been mentioned as the sporulation inducer and stimulatory agent for antimicrobial compound production (Berkley et al. 1984; Peypoux et al. 1999; Wei and Chu 2002).

The time course of production of antimicrobial compound indicated that the maximum antimicrobial activity was produced on the $3^{\text {rd }}$ day of fermentation and decreased thereafter. The findings of this study are similar to those reported previously. It has been reported that most of the Bacillus antimicrobial compounds are produced by in the late log phase, may be due to sporulation (Katz and Demain 1977). It was speculated initially that decrease in the activity after $3^{\text {rd }}$ day might be due to protease production. Therefore, protease production was also monitored during fermentation cycle.

Since Bacillus species are reported to produce peptide antibiotics and proteases as well and it is also possible that protease enzymes catalyze the cleavage of peptide bonds of the protein based antimicrobial compound and makes it inactive. It was believed earlier that a molecule of gramicidin $\mathrm{S}$ is stable to proteolytic enzymes due to the presence of two residues of D-phenylalanine in its structure. But various studies have shown that the production of proteinase by Bacillus subtilis during antibiotic production is responsible for hydrolysis of polypeptide antibiotic gramicidin S. It has been reported that enzyme gramicidinase formed during sporulation can reduce $45 \%$ of gramicidin S after $24 \mathrm{~h}$ incubation at $37^{\circ} \mathrm{C}$. Similarly, enzyme nisinase produced by Bacillus polymyxa is responsible for inactivation of nisin (Jarvis 1967; Katz and Demain 1977; Stein 2005 ). Unlike previous studies, the protease production during fermentation was negligible and was constant during whole fermentation cycle. Hence, there could role of other factors in the reduced activity after $3^{\text {rd }}$ day of fermentation.

In the present study, the cell-free culture supernatant of the organism was tested for antibacterial activity and susceptibility to enzymes, organic solvents, and to high and low temperature. The antimicrobial activity of $B$. subtilis KBB was partially susceptible to proteinase $\mathrm{K}$, pronase and chymotrypsin, suggesting that it is proteinaceous, as described previously (Jack et al. 1995; Korenblum et al. 2005). The common organic solvents such as methanol, ethanol, chloroform etc. did not affect the activity of the antimicrobial compound as reported previously (Korenblum et al. 2005).
Present study showed that the antimicrobial compound produced by Bacillus subtilis $\mathrm{KBB}$ seems to be highly thermostable and found active over a wide range of acidic and basic $\mathrm{pH}$. The activity of culture supernatant was not affected by heating below $60^{\circ} \mathrm{C}$ but slightly reduced activity was observed after heating the supernatant at $100^{\circ} \mathrm{C}$. However, the inhibitory activity of the antimicrobial compound was lost after autoclaving $\left(121^{\circ} \mathrm{C}\right.$ for $\left.15 \mathrm{~min}\right)$. Similar to the results of the present study, production of thermo-stable antimicrobial substances with stable activity at broad range of $\mathrm{pH}$ by Bacillus spp. in culture supernatant has been widely reported previously (Phae et al. 1990; Leddabi et al. 1994; Doss and Tyejegaja 1996; Motta and Brandelli 2002). Similarly, Bacillin, produced by B. subtilis retains antimicrobial activity even after heating at 100ÚC for 30 min. under acidic conditions (pH 6.5) (Stein 2005). The peptide antibiotic ericin $\mathrm{S}$ remains fully stable and bioactive even after heating at 60ÚC, but gradually lost its activity at temperature above 60ÚC, and lost $80 \%$ antimicrobial activity after heating at 100 ÚC for $90 \mathrm{~min}$. (Stein et al. 2002). Regarding the storage stability and shelf life, the antimicrobial compound does not undergo any kind of degradation during storage at cold temperature for a month and at room temperature for 4 month.

In the present study, extraction of antimirobial compound was optimized by one-step solvent extraction procedure using Bligh and Dyer method (1959) with slight modification. In this method the proportions (Metahanol 4: supernatant 2 : chloroform 1) of both the methanol and chloroform should be accurate otherwise the precipitate residue cannot be obtained. The partial purification of antimicrobial compound was performed with successive solvent washing. Protein nature of the partially purified compound was confirmed by Biuret test and Ninhydrin test. The purity of the compound was confirmed by TLC as only one spot $(\mathrm{Rf}=0.5)$ was observed with TLC and bioactivity was confirmed by bioautography. It can be concluded that the method of extraction and purification followed in present study resulted in extraction of single bacteriocin (though it has been considered as partially purified antimicrobial compound). MIC of the compound was $125 \mathrm{ig} / \mathrm{ml}$ for S. aureus and $250 \mathrm{ig} / \mathrm{ml}$ for Salmonella Typhi W7 indicates broad spectrum but more suitable for gram-positive bacteria.

In present study, although GCMS and NMR, UV, IR spectrum all are suggesting the peptide nature of the compound (The spectra are presented in annex 3) but complete structure elucidation was not done. The molecular weight of antimicrobial compound was aprox.14 KD as revealed by SDS page. However, complete chemical formula of the bioactive molecule could not be elucidated in present study.

\section{REFERENCES}

Abee, T. (1995) Pore forming Bacteriocins of Gram-positive Bacteria and Self Protection Mechanisms of Producer organisms. FEMS Microbiol Lett 129, 1-10. 
Barefoot, S.F. and Nettles, E.G. (1993) Antibiosis revisited: bac-teriocins produced by dairy starter cultures. J Dairy Sci 76, 2366-2379.

Bauer, A. W., Kirby, M. W., Sherris, J. C. and Turck, M. (1966) Antibiotic susceptibility testing by a standardized single disc method. Am J Clin Pathol 45, 493-496.

Berdy, J. (1974). Recent developments of antibiotic research and classification of antibiotics according to chemical structure. Adv Appl Microbiol 18, 309-406.

Berkeley, R.C.W., Logan,N.A., Shute, L.A and Capey, A.G. (1984) Identification of Bacillus species In: Methods in microbiology vol, 16, pp. 292-323, Acedemic press, London.

Bie, X., Lu, Z. and Lu, F. (2006) Preservative Effect of an Antimicrobial Substance from Bacillus subtilis fmbJ on Pasteurised Milk During Storage. Food Sci Technol International 12, 189194.

Bizani, D., Motta, A.S., Morrissy, J.A.C., Terra, R.M.S., Saouto A.A., Brandelli, A. (2005) Antibacterial activity of cerein 8A, a bacteriocin-like peptide produced by Bacillus cereus. International Microbiol 8, 125-131.

Braoudaki, M., Hilton, A. C. (2004). Adaptive Resistance to Biocides in Salmonella enterica and Escherichia coli O157 and CrossResistance to Antimicrobial Agents. J. Clin. Microbiol. 42: 7378.

Buswell, C. M., Herlihy, Y. M., Lawrence, L .M., McGuiggan, J. T M., Marsh, P. D.,Keevil, C. W.,and Leach, S.A. (1998) Extended Survival and Persistence of Campylobacter spp. in Water and Aquatic Biofilms and Their Detection by ImmunofluorescentAntibody and -rRNA Staining. Appl Environ Microbiol. 64, 733741.

Carrillo, C., Teruel, J.A., Aranda, F.J., and Ortiz, A. (2003) Molecular mechanism of membrane permeabilization by the peptide antibiotic surfactin. Biochim Biophys Acta 1611: 91-9.

Chopra, I., Hodgson, J., Metcalf, B. and Poste, G. (1997) The search for antimicrobial agents effective against bacteria resistant to multiple antibiotics. Antimicrob Agents Chemother 41, 497503.

Chopra, I.,Hesse, L., and O’Neil, A.J. (2002)Exploiting current understanding of antibiotic action for discovery of new drugs. $J$ Appl Microbiol, 92 (s1), 4S-15S.

Claus, D., and Berkeley, R. C. W. (1986) Genus Bacillus Cohn1872, 174 In : Bergey's Manual of Systematic Bacteriology vol. 2 ed. Sneath, P. H. A. Mair, N. S. Sharpe, M. E. and Holt J. G. pp 11041139. The Williams \& Wilkins Co., Baltimore.

Davidson, P.M. and Harrison, M.A. (2002) Resistance and adaptation to food antimicrobials, sanitizers, and other process controls. Food Technol 56, 69-78.

Doss, C. and Tejegya, R. (1996) growth and suppression of some wood decay fungi by Bacillus subtillis. Australian J Bot 44, 705112

Fox, S.L., and Bala, G.A. (2000) Production of surfactant from Bacillus subtilis ATCC 21332 using potato substrates. Bioresour Technol $75,235-240$

Gilbert, P., Allison, D. G. and McBain, A. J. (2002)Biofilms in vitro and in vivo, do singular mechanisms imply cross-resistance?. $J$ Appl Microbiol 92, 98S-110S.

Gilbert, P., McBain, A. J. (2003). Potential Impact of Increased Use of Biocides in Consumer Products on Prevalence of Antibiotic Resistance. Clin. Microbiol. Rev. 16: 189-208.
Hancock, R. E. W. and Chapple, D. S. (1999) Peptide antibiotics. Antimicrob Agents Chemother 43, 1317-1323.

Hara, T., and Ueda, S. (1982) Regulation of polyglutamate in Bacillus subtilis (natto): transformation of high PGA productivity Agric Biol Chem 46, 2275-2281.

Inaoka, T., Takahashi, K., Ohnishi-Kameyama, M., Yoshida, M., and Ochi, K. (2003) Guanine nucleotides guanosine 5'-diphosphate 3'-diphosphate and GTP co-operatively regulate the production of an antibiotic bacilysin in Bacillus subtilis. J Biol Chem 278, 2169-2176.

Inaoka, T., Takahashi, K., Yada, H., Yoshida, M., and Ochi, K. (2004) RNA polymerase mutation activates the production of a dormant antibiotic 3,3'-neotrehalosadiamine via an autoinduction mechanism in Bacillus subtilis. J Biol Chem 279, 3885-3892.

Jack, R. W., Tagg, J. R. and Ray, B. (1995) Bacteriocins of grampositive bacteria. Microbiol Rev 59, 171-200.

Jansen, E. F., and Hirschmann, D. J. (1944) Subtilin, an antibacterial factor of Bacillus subtilis: culturing condition and properties. Arch. Biochem 4, 297-309.

Katz, E. and Demain, A. L. (1977). The peptide antibiotics of Bacillus: chemistry, biogenesis and possible functions. Bacteriol Rev 40, 449-474.

Klaenhammer, T. R. (1993) Genetics of bacteriocins by lactic acid bacteria. FEMS Microbiol Rev 12, 39-86.

Korenblum,E., von der Weid, I., Santos, A.L.S., Rasado, A.S., Sebastian, G.V., Coutinho, C.M.L.M., Magalhaes, F.C.M., de Paiva, M.M and Seldin, L. (2005) Production of antimicrobial substances by Bacillus subtilis LFE1, B.firmus H2O-1 and B. licheniformis T65, isolated from an oil reservoir in Brazil. J Appl Microbiol 98, 667-675.

Leclere,V., Marti,R., Bechet.M., Fickers.P. and Jacques, P. (2006) The lipopeptides mycosubtilin and surfactin enhance spreading of Bacillus subtilis strains by their surface-active properties. Arch Microbiol 186, 475-481.

Leddabi, M., Galvez, A., Maqueda, M., Martinez-Bueno, M. and Valdivia, E. (1994) Fungicin M4: a narrow spectrum peptide antibiotic from Bacillus licheniformis M-4. J Appl Bacteriol 77, 49-53.

Maillard, J.-Y. (2002) Antibiotic and biocide resistance in bacteria: perceptions and realities for the prevention and treatment of infection. J Appl Microbiol 92, viiS.

Motta, A.S. and Brandelli, A. (2002) Characterization of an antibacterial peptide produced by Brevibacterium linens. J Appl Microbiol 92, 63-70.

Mulligan, C.N., Yong, R.N., and Gibbs, B.F. (2001) Surfactant enhanced remediation of contaminated soil: a review. Eng Geol (Amsterdam) 60, 371-380.

NCCLS (1997) National Committee for Clinical Laboratory Standards (M 2-A6) Performance Standards for Antimicrobial Disc Susceptibility Tests, 6th edn. PA, USA: Wayne.

NCCLS (1997), National committee for Clinical Laboratory Standards (M 7-A4), Methods for dilution antimicrobial susceptibility tests for bacteria that grow aerobicalyly. $4^{\text {th }}$ ed.

NCCLS (2002) Performance Standards for Antimicrobial SusceptibilityTesting; Twelfth Informational Supplement 2002. NCCLS Document M100-S12. PA, USA: Wayne.

Newton, B. A. (1956) The properties and mode of action of the polymyxins. Bact Rev 20, 14-18. 
Nicholson, W.L. (2002) Roles of Bacillus endospores in the environment. Cell Mol Life Sci 59, 410-416.

Paik, H. D., Lee, N.K., Lee, H.K., Hwang, Y.I. and Pan, J. C. (2000) Identification and partial characterization of cerein BS229, bacteriocin produced by Bacillus cereus BS229. J Microbiol Biotechnol 10, 195-200.

Pattnaik, P., Kaushik, J. K. Grover, S. and Batish, V. K. (2001) Purification and characterization of a bacteriocin-like compound (lichenin) produced anaerobically by Bacillus licheniformis isolated from water buffalo. J Appl Microbiol 91, 636-645.

Peypoux, F., Bonmatin, J.M., and Wallach, J. (1999) Recent trends in the biochemistry of surfactin. Appl Microbiol Biotechnol 51, 553 563.

Pinchuk, I.V., Bressollier, P., Sorokulova, I.B., Verneuil, B., and Urdaci, M.C. (2002) Amicoumacin antibiotic production and genetic diversity of Bacillus subtilis strains isolated from different habitats. Res Microbiol 153, 269-276.

Priest, F. G. (1993) Systematics and ecology of Bacillus, pp 3-16, In Sonenshein, A. L., Hoch, J. A., and Losick, R. (ed.), Bacillus subtilis and other gram-positive bacteria: biochemistry, physiology, and molecular genetics. American Society for Microbiology, Washington, D.C.

Priest, F. G. and Girgorova, R. (1991) Methods for studying the ecology of endospore-forming bacteria, pp 565-591,In Grigorova, R. and Norris, J. R. (ed.), Methods in microbiology, vol 22, Academic Press, London, U.K.

Rosenberg, E., and Ron, E.Z. (1999) High and low-molecular-mass microbial surfactants. Appl Microbiol Biotechnol 52, 154-162.

Sahl, H.G, and Bierbaum, G. (1998) Lantibiotics: Biosynthesis and Biological Activities of Uniquely Modified Peptides from GramPositive Bacteria Annu. Rev Microbiol 52, 41-79.

Sahl, H.G., Jack, R.W., Bierbaum, G. (1995) Biosynthesis and biological activities of lantibiotics with unique post-translational modifications. Eur J Biochem 230, 827-53.

Schallmey, M., Singh, A. and Ward, O.P. (2004) Developments in the use of Bacillus species for industrial production. Can $J$ Microbiol 50, 1-17.

Seah, A. H. L., Teo, A. Y.L. and Tan, H.M. (2002) Antimicrobial compounds from Bacillus subtilis for use against animal and human pathogens. U.S. Patent and Trademark Office serial no. 10/ 306,365 .
Stackbrandt, E.,and Goebel,B.M.(1994) taxonomic note A place for DNA DNA reassociation and 16SrNA sequence analysis in the present species definition in bacteriology .Int Jsyst Evol Microbiol 44, 846-849.

Stein, T. (2005) Bacillus subtilis antibiotics: structures, syntheses, and specific functions. Mol Microbiol 56, 845-857.

Stein, T., Borchert, S., Conrad, B., Feesche, J., Hofemeister, B., Hofemeister, J., and Entian, K. D. (2002) Two different lantibiotic-like peptides originate from the ericin gene cluster of Bacillus subtilis A1/3. J Bacteriol 184, 1703-1711.

Steinborn, G., Hajirezaei, M.R. and Hofemeister, J. (2005) Bac genes for recombinant bacilysin and anticapsin production in Bacillus host strains. Arch Microbiol 183, 71-79.

Stickler D.J.( 2002)Susceptibility of antibiotic-resistant Gram-negative bacteria to biocides: a perspective from the study of catheter biofilms. J Appl Microbiol 92, 163S-170S.

Stover, A.G. and Driks, A. (1999) Regulation of synthesis of the Bacillus subtilis transition-phase, spore-associated antibacterial protein TasA. J Bacteriol 181, 5476-5481.

Tamehiro, N., Okamoto-Hosoya, Y., Okamoto, S., Ubukata, M., Hamada, M., Naganawa, H., and Ochi, K. (2002) Bacilysocin, a novel phospholipid antibiotic produced by Bacillus subtilis 168 . Antimicrob Agents Chemother 46: 315-320.

Teo, Y.A. and Tan, H.M (2005) Inhibition of Clostridium perfringens by a Novel Strain of Bacillus subtilis Isolated from the Gastrointestinal Tracts of Healthy Chickens. Appl Environ Microbiol 71, 4185-4190.

Wei, Y.H., Chu, I.M. (2002) $\mathrm{Mn}^{2}+$ improves surfactin production by Bacillus subtilis. Biotech Lett 24, 479-482.

Yazgan, A., Cetin, S., and Ozcengiz, G. (2003) The effects of insertional mutations in $\mathrm{ComQ}$, comP, srfA, spoOH, spoOA and $a b r B$ genes on bacilysin biosynthesis in Bacillus subtilis. Biochim Biophys Acta 1626, 51-56.

Yoshida,S., Hiradate, S., Tsukamoto, T., Hatakeda, K. and Shirata, A. (2001) Antimicrobial Activity of Culture Filtrate of Bacillus amyloliquefaciens RC-2 Isolated from Mulberry Leaves. American Phyto path Society 91, 181- 187.

Zheng, G. and Slavic, M.F. (1999) Isolation, partial purification and characterization of a bacteriocin produced by a newly isolated Bacillus subtilis strain. Lett Appl Microbiol 28, 363-367. 